\title{
NANOENKAPSULASI EKSTRAK KULIT MELINJO MERAH (Gnetum gnemon L.) PADA BERBAGAI SUHU INLET DAN LAJU ALIR SPRAY DRYER
}

\section{Nanoenkapsulation of Melinjo (Gnetum gnemon L.) Red Peels Extract in Various Inlet Temperatures and Flow Rates on Spray Dryer}

\author{
Bambang Kunarto* dan Iswoyo \\ Jurusan Teknologi Hasil Pertanian - Fakultas Teknologi Pertanian - Universitas Semarang \\ Jl. Soekarno-Hatta, Tlogosari - Semarang 59160 \\ *Penulis Korespondensi, email: bambangkun@usm.ac.id
}

Disubmit :17 November 2020 Direvisi : 17 Oktober $2021 \quad$ Diterima : 22 Desember 2021

\begin{abstract}
ABSTRAK
Kulit melinjo merah berpotensi sebagai sumber antioksidan. Enkapsulasi perlu dilakukan untuk melindungi ekstrak kulit melinjo merah yang kurang stabil. Tujuan penelitian ini adalah nanoenkapsulasi ekstrak etanolik kulit melinjo merah menggunakan enkapsulan $\beta$ siklodekstrin melalui tahap nanomulsifikasi dengan berbagai konsentrasi surfaktan poloksamer $(0,5 ; 1$, dan 1,5\%). Selanjutnya dilakukan spray drying pada berbagai suhu inlet $(120 ; 130$, dan 140 ${ }^{\circ} \mathrm{C}$ ) dan laju alir bahan $(4,5$, dan $6 \mathrm{ml} /$ menit). Hasil penelitian menunjukkan bahwa nanoemulsi dengan ukuran 99,32 $\pm 0,32 \mathrm{~nm}$, indeks polidispersitas 0,29 $\pm 0,04$, viskositas 2,97 $\pm 0,53 \mathrm{cp}$, turbiditas 197,56 \pm 0,20 NTU dan potensial zeta $-34,25 \pm 0,04 \mathrm{mV}$ diperoleh dengan penambahan poloksamer $1 \%$. Spray drying pada suhu inlet $130{ }^{\circ} \mathrm{C}$ dan laju alir $5 \mathrm{ml} / \mathrm{menit} \mathrm{mampu}$ menghasikan nanokapsul ekstrak etanolik kulit melinjo merah dengan yield 31,98 $\pm 0,11 \%$, efisiensi enkapsulasi 83,28 \pm 0,16\% dan aktivitas antioksidan (RSA-DPPH 69,94 \pm 0,07\% dan reducing power $77,57 \pm 0,43 \%$ )
\end{abstract}

Kata kunci: $\beta$-siklodekstrin; Kulit Melinjo Merah; Poloksamer; Spray Drying

\begin{abstract}
Melinjo red peels has the potential as a source of antioxidants. Encapsulation is needed to protect the unstable melinjo red peels extract. The aim of this study was to nanoencapsulate the ethanolic extract of melinjo red peels using $\beta$-cyclodextrin encapsulants through the nanomulsification stages with various concentrations of poloxamer surfactants $(0.5 ; 1$ and $1.5 \%)$. Furthermore, spray drying was carried out at various inlet temperatures $\left(120 ; 130\right.$ and $\left.140{ }^{\circ} \mathrm{C}\right)$ and material flow rates $(4 ; 5$ and 6 $\mathrm{ml} / \mathrm{min})$. The results showed that the nanoemulsion with a particle size of $99.32 \pm 0.32 \mathrm{~nm}$, polydispersity index $0.29 \pm 0.04$, viscosity $2.97 \pm 0.53 \mathrm{cp}$, turbidity $197.56 \pm 0.20 \mathrm{NTU}$ and zeta potential $-34.25 \pm 0.04 \mathrm{mV}$ was obtained by adding 1\% poloxamer. Spray drying at an inlet temperature of $130{ }^{\circ} \mathrm{C}$ and a flow rate of $5 \mathrm{ml} / \mathrm{min}$ was able to produce nanocapsules of ethanolic extract from melinjo red peels with a yield of $31.98 \pm 0.11 \%$, encapsulation efficiency $83.28 \pm 0.16 \%$ and antioxidant activity (RSA-DPPH $69.94 \pm 0.07 \%$ and reducing power $77.57 \pm 0.43 \%$ )
\end{abstract}

Keywords: $\beta$-cyclodextrin; Melinjo Red Peels; Poloxamer; Spray Drying 
Jurnal Teknologi Pertanian Vol. 22 No. 3 [Desember 2021] 211-220

Nanoenkapsulasi Ekstrak Kulit Melinjo Merah pada Berbagai Suhu Inlet dan Laju Air Spray Dryer [Kunarto dkk]

\section{PENDAHULUAN}

Tanaman melinjo (Gnetum gnemon L.) merupakan salah satu komoditas perkebunan yang prospektif dikembangkan di Indonesia, karena mempunyai nilai ekonomi tinggi. Hasil utama tanaman melinjo adalah buah melinjo yang mana daging bijinya dapat dibuat tepung, kripik, emping, atau produk pangan lainnya. Namun kulit buahnya belum banyak dimanfaatkan. Menurut Apriliyanti et al. (2018), kulit buah melinjo berpotensi sebagai sumber antioksidan. Kulit melinjo merah yang diekstrak oleh Devina (2011) menggunakan pelarut etanol dan etil asetat (20:80) pada suhu $30{ }^{\circ} \mathrm{C}$ selama 3 jam mempunyai aktivitas antioksidan 1723,231 ppm, mengandung beta karoten 255,20 ppm, total fenol 11,805 mg GAE/mg ekstrak, dan vitamin C 1,153 mg/g ekstrak. Antioksidan dari kulit melinjo merah diharapkan dapat dipakai sebagai antioksidan alami pada pangan yang cukup aman karena penggunaan antioksidan sintetis (BHA, BHT, TBHQ, dan PG) dalam proses pengolahan pangan telah banyak menimbulkan kekhawatiran akan efek sampingnya.

Senyawa bioaktif yang terkandung dalam kulit melinjo bersifat kurang stabil, sehingga perlu dilindungi dari degradasi fisik dan kimia akibat pengolahan maupun pengaruh lingkungan. Melalui teknologi enkapsulasi, senyawa bioaktif dapat dipertahankan stabilitasnya dalam penyimpanan (Dube et al., 2010). Secara umum nanoenkapsulasi bertujuan untuk melindungi komponen senyawa bioaktif, mengurangi kehilangan nutrisi, mengubah komponen bahan cair ke bentuk padat yang lebih mudah ditangani dan diaplikasikan dalam sistem pangan. Nanoenkapsulasi menggunakan metode kompleks inklusi dengan enkapsulan $\beta$-siklodekstrin telah terbukti paling efektif memberikan perlindungan pada senyawa aktif terhadap panas dan penguapan (Kalogeropoulos et al., 2010). Nanoenkapsulasi dengan metode ini diawali dengan pembuatan nanopartikel atau nanoemulsi, kemudian pembuatan kompleks inklusi dan spray drying. Penambahan surfaktan dapat dilakukan untuk memperoleh ukuran nanopartikel yang lebih kecil (Chowdary dan Srinivasan, 2011; Surassmo et al., 2010; $\mathrm{Zu}$ et al., 2014). Penggunaan surfaktan dalam sintesis nanopartikel dapat mempengaruhi ukuran partikel, indeks polidispersitas, dan meningkatkan stabilitas nanoemulsi yang dihasilkan (Sugita et al., 2013; Yeni, 2015; Zhou et al., 2013). Konsentrasi surfaktan berpengaruh terhadap pembentukan nanoemulsi yang dihasilkan. Spray drying dipengaruhi oleh suhu inlet dan laju alir bahan. Suhu inlet berpengaruh pada evaporasi air bahan, sedangkan laju alir berpengaruh pada kecepatan bahan kontak dengan udara panas (Babu et al., 2019; Correâ-Filho et al., 2019).

Nanoenkapsulasi ekstrak etanolik kulit melinjo merah pada penelitian ini dilakukan menggunakan enkapsulan $\beta$-siklodekstrin melalui tahap nanomulsifikasi dengan berbagai konsentrasi surfaktan poloksamer. Selanjutnya dilakukan spray drying pada berbagai suhu inlet dan laju alir bahan.

\section{METODE}

Bahan baku untuk penelitan ini adalah kulit melinjo merah yang diperoleh dari daerah Limpung, kabupaten Batang, Jawa Tengah. Bahan kimia yang digunakan antara lain etanol (Merck, Jerman), distilled water, reagen folin-ciocalteu (Merck, Jerman), 2,2difenil-1-pikrillhidrazil (Sigma, USA), $\mathrm{K}_{3}\left[\mathrm{Fe}(\mathrm{CN})_{6}\right]$ (Merck), buffer fosfat, asam askorbat (Merck), $\mathrm{CCl}_{3} \mathrm{COOH}$ (Merck), $\mathrm{FeCl}_{3}$ (Merck), poloksamer (Sigma-Aldrich) dan $\beta$ siklodekstrin. Semua reagen yang digunakan berkualitas pro analisis.

Peralatan yang digunakan antara lain freeze dryer (Edwards Modulyo, United Kingdom), grinder (Maksindo, Indonesia), ayakan (ASTM Standart, Indonesia), timbangan analitik (OHOUS PA 214, USA), sonicator bath 3800 (Branson, Mexico), rotary vacuum evaporator (Heidolph, Germany), spektrofotometer (GENESYS 10S double beam), Malvern Zetasizer (Nano ZS, Malvern Instrument, UK), vortex (VELP type ZX 3, USA), waterbath (Memmert type: WNB 14 Germany), CAMAG TLC Scanner 4 (Muttenz, Switzerland), turbidimeter (Lovibond TurbiCheck SN 10/23748), spray dryer (Buchi, Switzerland) dan viskosimeter (Brookfield DV2T).

Diagram alir penelitian dapat dilihat pada Gambar 1. Ekstraksi dilakukan dengan metode berbantu gelombang ultrasonik. Kulit melinjo merah dikeringbekukan, lalu digiling sehingga 
menjadi bubuk lolos 30 mesh. Bubuk kulit melinjo kering beku sebanyak $20 \mathrm{~g}$ dimasukkan dalam gelas beaker, kemudian ditambah pelarut etanol $70 \%$ dengan rasio bahan dan pelarut 1:10 (b/v). Sampel tersebut diekstraksi pada ultrasonic bath frekwensi 40 $\mathrm{kHz}$ pada suhu $30^{\circ} \mathrm{C}$ selama 32 menit. Ekstrak disaring dan dipekatkan menggunakan rotary vacuum evaporator. Ekstrak etanolik kulit melinjo merah dikeringbekukan menggunakan freeze dryer dan disimpan untuk perlakuan selanjutnya. Ekstraksi maserasi untuk membandingkan yield dilakukan pada kondisi suhu, waktu dan konsentrasi pelarut yang sama dengan metode ekstraksi berbantu gelombang ultrasonik, yaitu suhu $30{ }^{\circ} \mathrm{C}$, waktu 32 menit dan konsentrasi pelarut etanol $70 \%$.

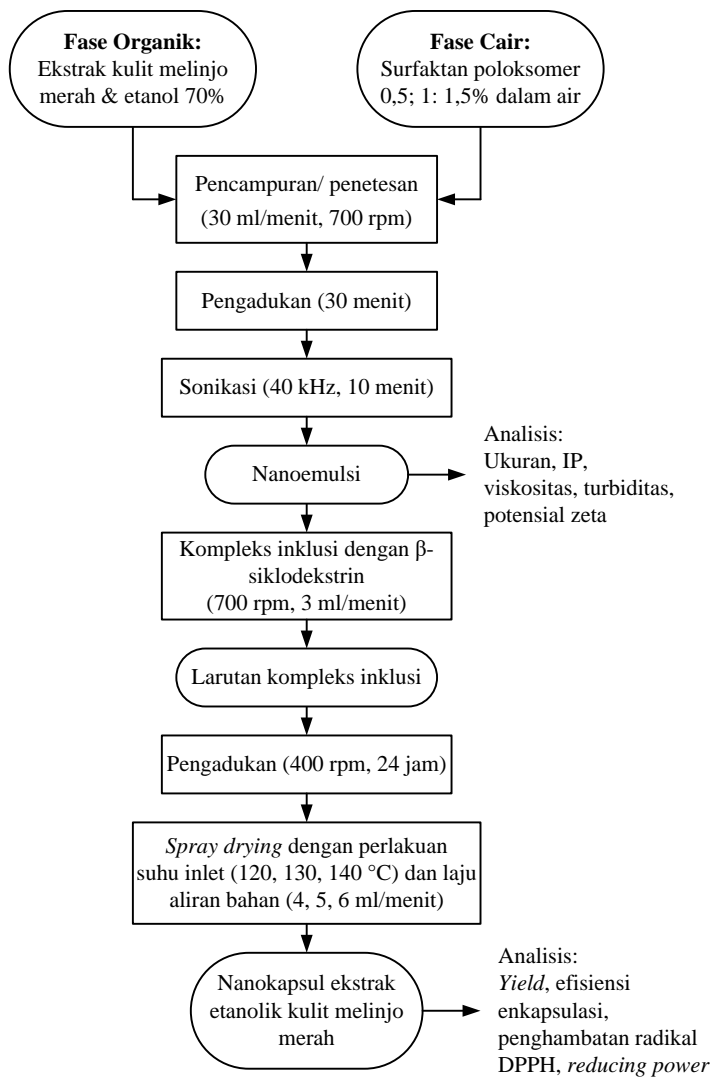

Gambar 1. Diagram alir penelitian

Nanoenkapsulasi metode kompleks inklusi dilakukan dengan modifikasi dari Savić-Gajić et al. (2017), Yeni (2015), dan Chowdary dan Srinivasan (2011). Ekstrak etanolik kering beku kulit melinjo merah dilarutkan dalam etanol 70\% dengan rasio 30:50 $(\mathrm{b} / \mathrm{v})$. Selanjutnya dilakukan pengadukan menggunakan magnetic stirrer dengan kecepatan putaran $700 \mathrm{rpm}$ selama 30 menit dan diukur menggunakan Particle Size Analyzer (PSA), meliputi ukuran diameter nanopartikel dan indeks polidispersitas. Surfaktan poloksamer digunakan untuk lebih menurunkan ukuran nanopartikel (Yeni, 2015). Fase organik dibuat dengan melarutkan $30 \mathrm{mg}$ ekstrak etanolik kulit melinjo merah ke dalam $50 \mathrm{ml}$ etanol $70 \%$. Fase cair dibuat dengan melarutkan surfaktan poloksamer dalam $50 \mathrm{ml}$ air dengan konsentrasi berturut-turut 0,5, 1, dan 1,5\%, kemudian diaduk menggunakan magnetic stirrer. Fase organik ditambahkan ke dalam fase cair sambil diaduk pada kecepatan 700 rpm dengan penetesan $3 \mathrm{ml} /$ menit. Pengadukan dilanjutkan selama 30 menit dan disonikasi $40 \mathrm{kHz}$ selama 10 menit untuk membentuk droplet nanoemulsi. Nanoemulsi dianalisis ukuran partikel, indeks polidispersitas, viskositas, turbiditas dan potensial zeta. Kondisi proses terbaik dipilih berdasarkan ukuran partikel yang paling kecil.

Nanoemulsi ekstrak etanolik kulit melinjo merah terpilih dikompleks-inklusikan dengan larutan $\beta$-siklodekstrin (149 mg $\beta$-siklodekstrin dalam $50 \mathrm{ml}$ distilled water) sesuai prosedur Savić-Gajić et al. (2017), dengan jumlah penetesan $3 \mathrm{ml} /$ menit pada kecepatan putaran $700 \mathrm{rpm}$. Setelah penetesan nanoemulsi selesai, pengadukan dengan magnetic stirrer pada kecepatan putaran $400 \mathrm{rpm}$ dilanjutkan selama 24 jam. Kompleks inklusi yang terbentuk dikeringkan menggunakan spray drying pada berbagai suhu inlet berturut-turut 120, 130, dan $140{ }^{\circ} \mathrm{C}$ dan laju alir bahan berturut-turut 4,5 , dan $6 \mathrm{ml} /$ menit.

\section{Ukuran Partikel dan Potensial Zeta (Sukhbir et al., 2016)}

Dispersi nanopartikel dan nanoemulsi masing-masing dalam aquades diukur menggunakan alat laser particle size analyzer (Malvern Zetasizer Nanoseries Nano ZS ver 6.20, Malvern Instruments Ltd, Malvern, UK) dengan metode Dynamic Light Scattering. Sampel diencerkan dan disaring dengan syringe filter membrane dengan ukuran 0,40 $\mathrm{mm}$. Nilai viskositas, indeks refraksi dan suhu berturut turut $0,8872 \mathrm{cP}, 1,330$, dan $25^{\circ} \mathrm{C}$.

\section{Efisiensi Penjerapan (Shrotriya et al., 2017)}

Sampel disentrifugasi pada $17.000 \mathrm{rpm}$. Ekstrak bebas pada supernatan ditentukan dengan thin layer chromatograph. Efisiensi penjerapan (EP) dihitung dengan Persamaan (1). 
Jurnal Teknologi Pertanian Vol. 22 No. 3 [Desember 2021] 211-220

Nanoenkapsulasi Ekstrak Kulit Melinjo Merah pada Berbagai Suhu Inlet dan Laju Air Spray Dryer [Kunarto dkk]

$\mathrm{EP}(\%)=\frac{\mathrm{Te}-\mathrm{Eb}}{\mathrm{Te}} \times 100$

Dimana Te adalah total ekstrak dan Eb adalah ekstrak bebas.

Yield Nanokapsul

Yield (rendemen) dihitung berdasarkan persentase rasio massa nanokapsul yang dihasilkan dengan total padatan.

\section{Efisiensi enkapsulasi (Dehcheshmeh dan Fathi, 2019)}

Perhitungan efisiensi enkapsulasi (EE) sesuai dengan Persamaan (2).

$\mathrm{EE}(\%)=\frac{\mathrm{Ea}-\mathrm{Ep}}{\mathrm{Ea}} \times 100$

Dimana Ea adalah ekstrak awal dan Ep adalah ekstrak di permukaan.

\section{Penghambatan Radikal DPPH}

(Savić-Gajić et al., 2017)

Larutan DPPH $1 \mathrm{ml}$ ditambahkan ke dalam 2,5 ml ekstrak etanolik kulit melinjo merah. Setelah dikocok, campuran diinkubasi pada kondisi gelap (suhu kamar) selama 30 menit, kemudian diukur absorbansinya pada 517 nm. Penghambatan radikal DPPH dihitung dengan Persamaan (3).

Penghambatan $(\%)=\frac{A c-A s}{A c} \times 100$

Dimana Ac adalah absorbansi kontrol dan As adalah sampel.

\section{Reducing Power (Ozsoy et al., 2008)}

Ekstrak etanolik kulit melinjo merah sebanyak $1 \mathrm{mg}$ dicampur dengan buffer fosfat $(2,5 \mathrm{ml})$ dan kalium feri sianida $(2,5 \mathrm{ml})$. Selanjutnya campuran diinkubasi pada suhu $50{ }^{\circ} \mathrm{C}$ selama 20 menit. Asam triklor asetat sejumlah 2,5 $\mathrm{ml}$ ditambahkan ke dalam campuran, kemudian disentrifugsi selama 10 menit pada 3.000 $\mathrm{rpm}$. Sejumlah $2,5 \mathrm{ml}$ supernatan dicampur dengan $2,5 \mathrm{ml}$ distilled water dan $0,5 \mathrm{ml}$ larutan besi klorida. Absorbansi larutan diukur pada panjang gelombang $700 \mathrm{~nm}$. Persentase reducing power (RP) sampel dibandingkan dengan standar (asam askorbat) dan dihitung menggunakan Persamaan (4).

$$
\mathrm{RP}(\%)=\left(1-\left(\frac{1-\mathrm{As}}{\mathrm{Ac}}\right)\right) \times 100 \ldots
$$

Di mana Ac adalah absorbansi standar dan As adalah absorbansi sampel.

\section{Rancangan Percobaan}

Rancangan percobaan yang digunakan pada nanoenkapsulasi adalah Rancangan Acak Lengkap (RAL) dengan satu faktor, yaitu konsentrasi surfaktan $(0,5 ; 1 ; 1,5 \%)$. RAL juga digunakan pada spray drying dengan dua faktor, yaitu suhu inlet spray drier $(130,140$, dan $\left.150^{\circ} \mathrm{C}\right)$ dan kecepatan alir bahan $(4,5$, dan $6 \mathrm{ml} /$ menit). Hasil percobaan dinyatakan sebagai nilai rata-rata dan standar deviasi (SD). Analisa data statistik dilakukan dengan analysis of variance (ANOVA) dan jika terdapat perbedaan antar perlakuan maka dilanjutkan dengan uji lanjutan Duncan multiple range test (DMRT) pada taraf $5 \%$.

\section{HASIL DAN PEMBAHASAN}

\section{Hasil Ekstrak Etanolik Kulit Melinjo Merah}

Ekstraksi kulit melinjo merah menggunakan gelombang ultrasonik pada suhu $30{ }^{\circ} \mathrm{C}$, selama 32 menit, dan konsentrasi pelarut etanol $70 \%$ menghasilkan yield 14,48 \pm $0,02 \%(\mathrm{db})$. Hasil ini lebih tinggi jika dibandingkan dengan ekstraksi kulit melinjo merah dengan metode maserasi pada kondisi yang sama. Ekstraksi maserasi kulit melinjo merah pada kondisi yang sama menghasilkan yield $4,11 \pm 0,48 \%$.

Perbedaan ini dikarenakan aplikasi gelombang ultrasonik pada ekstraksi padatcair membentuk gelembung kavitasi yang menghancurkan sel kulit melinjo merah sehingga mempermudah penetrasi pelarut ke dalam jaringan sel. Menurut Bilgin dan Şahin (2013), penetrasi pelarut etanol menyebabkan pembengkakan dan hidrasi sehingga terjadi pembesaran pori-pori dinding sel, yang akan meningkatkan proses difusi pelarut etanol ke dalam jaringan sel bahan dan meningkatkan perpindahan massa. Falleh et al. (2012) juga menyatakan bahwa gelombang ultrasonik akan merusak struktur dinding sel tanaman dan mempercepat difusi pelarut melalui membran, sehingga sel menjadi lisis dan menjadi mudah dalam pelepasan isi sel. Hasil ini sesuai dengan penelitian Tsai et al. (2014) bahwa yield ekstrak Phyllantus emblica L. menggunakan metode ekstraksi ultrasoundassisted mencapai 3,39 kali lebih tinggi dibandingkan ekstraksi konvensional. Oroian 
et al. (2020) juga melaporkan bahwa yield ekstrak propolis dengan metode ultrasonik lebih tinggi dibandingkan yield ekstrak menggunakan microwave maupun maserasi.

\section{Pengaruh Konsentrasi Poloksamer}

Berdasarkan nilai PSA (particle size analyzer), ekstrak etanolik kulit melinjo merah sebelum dikompleks inklusikan pada $\beta$-siklodekstrin berukuran $1.012 \pm 2,64 \mathrm{~nm}$ dengan IP (indeks polidispersitas) $0,967 \pm 0,06$. Hasil ini menunjukkan bahwa ukuran nanopartikel ekstrak etanolik kulit melinjo merah cukup besar dan tingkat kehomogenan yang rendah. Menurut Danaei et al. (2018), nilai indeks polidispersitas menunjukkan keseragaman ukuran. Semakin kecil nilai mengindikasikan ukuran yang semakin seragam. Nilai IP lebih kecil dari 0,3 menunjukkan sampel memiliki distribusi ukuran nanopartikel yang semakin sempit dan ukuran diameter nanopartikel makin seragam atau homogen. Pada penelitian ini dilakukan upaya penurunan ukuran partikel dengan menambahkan berbagai konsentrasi surfaktan poloksamer (Tabel 1).

Data Tabel 1 menunjukkan konsentrasi surfaktan poloksamer berpengaruh nyata $(p<0,05)$ terhadap nilai diameter ukuran partikel, indeks polidispersitas, viskositas, turbiditas dan potensial zeta emulsi yang dihasilkan. Penggunaan surfaktan polaksamer pada konsentrasi $0,5 \%$ menghasilkan ukuran partikel yang lebih besar dengan nilai turbiditas dan viskositas yang tinggi serta kenampakan yang cenderung keruh. Kondisi ini dapat disebabkan belum terjadinya kesetimbangan antara konsentrasi surfaktan dan ekstrak etanolik kulit melinjo merah. Konsentrasi surfaktan 1,5\% menghasilkan nilai turbiditas dan viskositas yang lebih tinggi dari konsentrasi surfaktan 1\% dan terjadi pemisahan antara 2 fase setelah selesai proses pengadukan. Hal tersebut dikarenakan kompleks yang terbentuk sudah melebihi konsentrasi kritis miselar. Menurut Surassmo et al. (2010), emulsi berukuran besar terjadi ketika konsentrasi surfaktan lebih rendah dari konsentrasi kritis miselar dan surfaktan yang digunakan belum cukup berperan mengurangi energi antarmuka antara senyawa aktif dan pelarut. Penggunaan surfaktan konsentrasi tinggi ditandai dengan partikel yang terbentuk dari reaksi sangat banyak dan padat, bergerombol membentuk agregat menjadi partikel berukuran mikro.

Potensial zeta menggambarkan stabilitas nanoemulsi karena perbedaan muatan antar partikel akan mempengaruhi gaya tolak menolak antar partikel. Nilai potensial zeta melebihi $+30 \mathrm{mV}$ atau kurang dari $-30 \mathrm{mV}$ menunjukkan kestabilan, karena muatan listrik dari droplet cukup kuat untuk menolak antara droplet yang dominan dalam sistem nanoemulsi (Salvia-Trujillo et al., 2013). Berdasarkan data ketiga nanoemulsi yang dihasilkan pada penelitian ini, ukuran partikel terkecil $(99,32 \pm$ $0,32 \mathrm{~nm}$ ) dengan indeks polidispersitas 0,29 \pm 0,04 dan nilai potensial zeta $-34,25 \pm 0,04 \mathrm{mV}$ (kurang dari $-30 \mathrm{mV}$ ) dimiliki oleh nanoemulsi dengan konsentrasi surfaktan poloksamer $1 \%$. Oleh karena itu, nanoemulsi dengan konsentrasi surfaktan poloksamer 1\% dipilih untuk dikompleksinklusikan dengan $\beta$-siklodekstrin.

Efisiensi penjerapan yang dihasilkan pada kompleks inklusi adalah 90,01 $\pm 0,79 \%$ dengan ukuran partikel 67,41 $\pm 0,61 \mathrm{~nm}$. Semakin kecil ukuran partikel maka nilai efisiensi penjerapan semakin tinggi karena partikel yang berukuran kecil dapat terinklusi dengan baik pada $\beta$ siklodekstrin. Yeni (2015) menyatakan bahwa ukuran partikel berpengaruh terhadap efisiensi enkapsulasi senyawa aktif pada $\beta$-siklodekstrin. Efisiensi enkapsulasi memiliki hubungan terbalik dengan ukuran partikel.

Tabel 1. Pengaruh konsentrasi surfaktan poloksamer terhadap diameter, indeks polidispersitas, viskositas, turbiditas, dan potensial zeta

\begin{tabular}{|c|c|c|c|c|c|}
\hline $\begin{array}{c}\text { Konsentrasi } \\
\text { poloksamer } \\
(\%)\end{array}$ & $\begin{array}{l}\text { Diameter } \\
\text { (nm) }\end{array}$ & $\begin{array}{c}\text { Indeks } \\
\text { polidispersitas }\end{array}$ & $\begin{array}{l}\text { Viskositas } \\
\quad(c p)\end{array}$ & $\begin{array}{l}\text { Turbiditas } \\
\text { (NTU) }\end{array}$ & $\begin{array}{l}\text { Potensial zeta } \\
\qquad(\mathrm{mV})\end{array}$ \\
\hline 0,5 & $294,00 \pm 5,0^{a}$ & $0,69 \pm 0,02^{a}$ & $8,87 \pm 0,08^{a}$ & $357,56 \pm 0,69 a$ & $-28,58 \pm 0,03^{c}$ \\
\hline 1 & $99,32 \pm 0,32^{c}$ & $0,29 \pm 0,04^{b}$ & $2,97 \pm 0,53^{c}$ & $197,56 \pm 0,20 c$ & $-34,25 \pm 0,04^{\mathrm{a}}$ \\
\hline 1,5 & $242,42 \pm 0,34^{\mathrm{b}}$ & $0,67 \pm 0,32^{a}$ & $4,48 \pm 0,16^{\mathrm{b}}$ & $298,63 \pm 0,47^{b}$ & $-30,82 \pm 0,51^{\mathrm{b}}$ \\
\hline
\end{tabular}


Jurnal Teknologi Pertanian Vol. 22 No. 3 [Desember 2021] 211-220

Nanoenkapsulasi Ekstrak Kulit Melinjo Merah pada Berbagai Suhu Inlet dan Laju Air Spray Dryer

[Kunarto dkk]

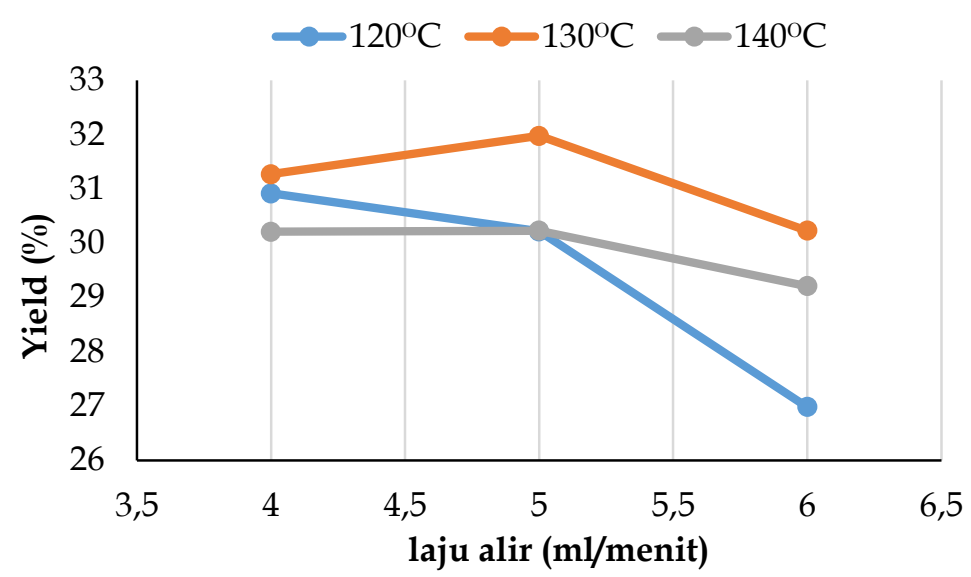

Gambar 2. Pengaruh kecepatan alir bahan dan suhu inlet spray drying terhadap yield nanokapsul ekstrak etanolik kulit melinjo merah

\section{Yield Nanokapsul Ekstrak Etanolik Kulit Melinjo Merah}

Suhu inlet spray drying dan laju alir berpengaruh nyata $(p<0,05)$ terhadap yield nanokapsul yang dihasilkan dan terdapat interaksi diantara keduanya. Gambar 2 menunjukkan pengaruh suhu inlet dan laju alir bahan terhadap yield nanokapsul ekstrak etanolik kulit melinjo merah. Hasil penelitian menunjukkan bahwa yield tertinggi diperoleh pada suhu inlet $130{ }^{\circ} \mathrm{C}$ dan laju alir bahan 5 $\mathrm{ml} /$ menit.

Suhu inlet yang lebih rendah dari $130{ }^{\circ} \mathrm{C}$ mengakibatkan laju evaporasi air menjadi lebih rendah sehingga nanokapsul menjadi lembab, kemudian menempel pada dinding chamber spray drying. Menurut Ali (2013), produk yang menempel di chamber tidak bisa digunakan sebagai sampel karena tidak berbentuk seperti serbuk dan bahkan cenderung mengkristal. Jika suhu inlet rendah, maka udara tidak cukup untuk mengeringkan produk sehingga ada sejumlah air yang masih terkandung dalam produk. Serbuk yang lembab mudah untuk menempel di dinding chamber dan berakibat pada berkurangnya yield (Krishnaiah et al., 2012). Hal ini sesuai dengan hasil penelitian tentang spray drying pada karamunting (Rhodomyrtus tomentosa) (Ho et al., 2015), buah asam (Muzaffar dan Kumar, 2015), murbei hitam (Fazaeli et al., 2012), dan jus delima (Jafari et al., 2017).

Semakin cepat laju alir bahan, maka yield nanokapsul ekstrak etanolik kulit melinjo merah yang dihasilkan juga semakin rendah. Nilai yield yang rendah pada laju alir bahan yang cepat disebabkan karena kontak udara panas dengan partikel terjadi lebih singkat sehingga air dalam partikel tidak seluruhnya teruapkan. Krishnaiah et al. (2012) dan Ali (2013) menyatakan bahwa jika laju alir larutan tinggi, maka air tidak bisa teruapkan pada waktu kontak yang singkat dengan udara panas sehingga produk tidak bisa dikeringkan dengan optimal dan serbuk yang dihasilkan lembab. Hasil ini sesuai dengan penelitian tentang spray drying pada konsentrat ceri asam (Karaca et al., 2016) dan elderberry (Murugesan dan Orsat, 2011).

\section{Efisiensi Enkapsulasi Nanokapsul Ekstrak Etanolik Kulit Melinjo Merah}

Pengaruh suhu inlet dan laju alir spray drying terhadap efisiensi enkapsulasi ditunjukkan pada Gambar 3. Suhu inlet spray drying dan laju alir berpengaruh nyata $(p<0,05)$ terhadap efisiensi enkapsulasi nanokapsul yang dihasilkan dan terdapat interaksi diantara keduanya. Efisiensi enkapsulasi mengalami peningkatan sampai suhu inlet $130{ }^{\circ} \mathrm{C}$, kemudian mengalami penurunan. Efisiensi enkapsulasi terbesar diperoleh pada perlakuan suhu inlet $130{ }^{\circ} \mathrm{C}$, dengan laju alir $5 \mathrm{ml} /$ menit yaitu sebesar $83,28 \pm 0,16 \%$.

Peningkatan efisiensi enkapsulasi sesuai dengan penelitian Shamaei et al. (2017) tentang mikroenkapsulasi minyak kenari dengan spray drying. Penurunan efisiensi enkapsulasi juga terjadi pada penelitian Paini et al. (2015) pada pengeringan minyak zaitun menggunakan spray dryer. 


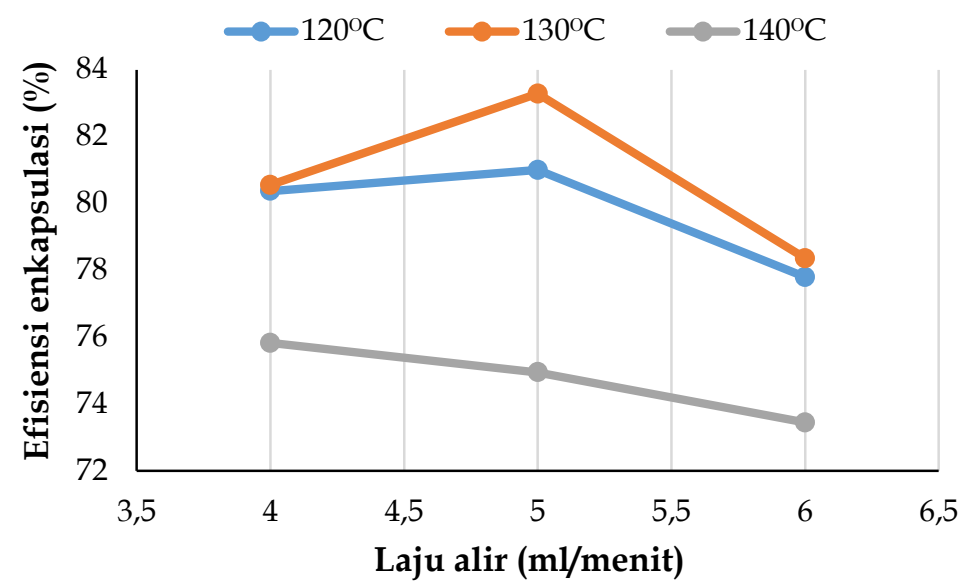

Gambar 3. Pengaruh kecepatan alir bahan dan suhu inlet spray drying efisiensi enkapsulasi nanokapsul ekstrak etanolik kulit melinjo merah

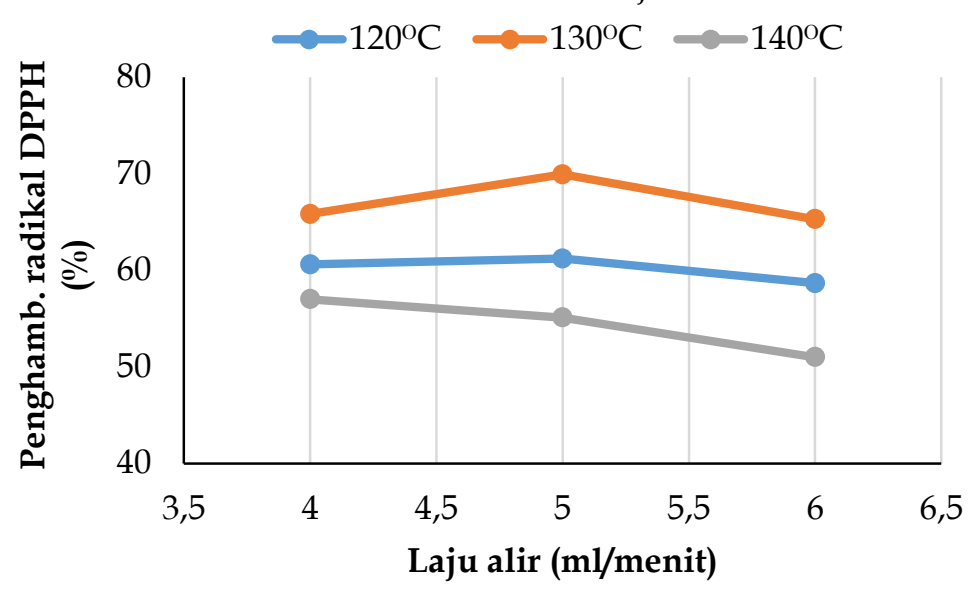

Gambar 4. Pengaruh kecepatan alir bahan dan suhu inlet spray drying penghambatan radikal DPPH nanokapsul ekstrak etanolik kulit melinjo merah

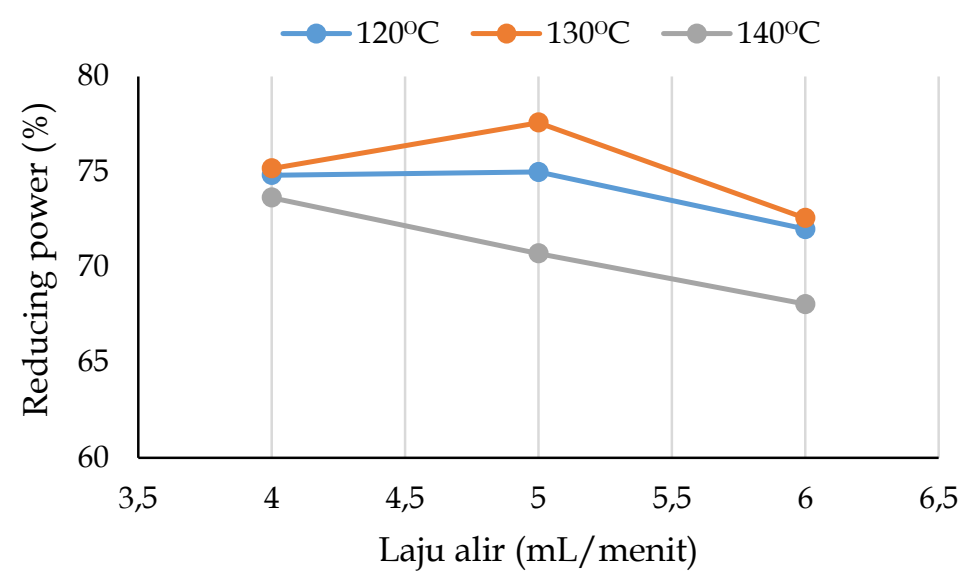

Gambar 5. Pengaruh kecepatan alir bahan dan suhu inlet spray dryer reducing power nanokapsul ekstrak etanolik kulit melinjo merah

Efisiensi enkapsulasi untuk parameter laju alir bahan meningkat sampai laju alir 5 $\mathrm{ml} /$ menit, setelah itu efisiensi menurun. Hal ini disebabkan oleh peningkatan suhu inlet dan laju alir bahan yang menjadikan proses pengeringan lebih baik sampai pada batas tertentu. Penurunan efisiensi enkapsulasi pada suhu inlet yang lebih tinggi dari $130^{\circ} \mathrm{C}$ dan laju alir bahan yang lebih tinggi dari $5 \mathrm{ml} /$ menit disebabkan oleh laju spray drying yang lebih tinggi. 
Jurnal Teknologi Pertanian Vol. 22 No. 3 [Desember 2021] 211-220

Nanoenkapsulasi Ekstrak Kulit Melinjo Merah pada Berbagai Suhu Inlet dan Laju Air Spray Dryer [Kunarto dkk]

Tingginya laju spray dying menunjukkan bahwa evaporasi menjadi lebih cepat, sehingga terjadi pengembangan yang tidak terkontrol dan kerusakan pada permukaan partikel. Berdasarkan data hasil penelitian menunjukkan bahwa efisiensi enkapsulasi tertinggi diperoleh pada suhu inlet spray drying $130^{\circ} \mathrm{C}$ dengan laju alir bahan $5 \mathrm{ml} /$ menit.

\section{Aktivitas antioksidan nanokapsul ekstrak etanolik kulit melinjo merah}

Aktivitas antioksidan ditunjukkan dengan nilai penghambatan radikal DPPH (Gambar 4) dan reducing power (Gambar 5). Suhu inlet spray drying dan laju alir berpengaruh nyata $(p<0,05)$ terhadap aktivitas antioksidan yang dihasilkan dan terdapat interaksi diantara keduanya, baik penghambatan radikal bebas DPPH maupun reducing power.

Aktivitas antioksidan meningkat seiring dengan meningkatnya suhu inlet maupun laju alir, namun menurun setelah suhu inlet $130^{\circ} \mathrm{C}$ dan laju alir $5 \mathrm{ml} /$ menit. Hal ini sesuai dengan tren efisiensi enkapsulasi karena aktivitas antioksidan nanokapsul ekstrak etanolik kulit melinjo merah dipengaruhi oleh ekstrak yang terkapsulan. Aktivitas antioksidan terbaik (penghambatan radikal DPPH 69,94 \pm 0,07\% dan reducing power $77,57 \pm 0,43$ ) diperoleh pada suhu inlet $130{ }^{\circ} \mathrm{C}$ dengan kecepatan alir 5 $\mathrm{ml} /$ menit.

Hasil penelitian ini sejalan dengan beberapa penelitian sebelumnya, antara lain enkapsulasi thymol dan carvacrol (Asprea et al., 2017), enkapsulasi eugenol (Talón et al., 2019), enkapsulasi norbixin (Tupuna et al., 2018), dan nanoenkapsulasi Mentha piperita (Royshanpour et al., 2021).

\section{SIMPULAN}

Nanoemulsi dengan ukuran 99,32 $\pm 0,32$ $\mathrm{nm}$, indeks polidispersitas $0,29 \pm 0,04$, viskositas $2,97 \pm 0,53 \mathrm{cp}$, turbiditas 197,56 \pm $0,20 \mathrm{NTU}$ dan potensial zeta $-34,25 \pm 0,04 \mathrm{mV}$ diperoleh dengan penambahan poloksamer $1 \%$. Spray drying pada suhu inlet $130{ }^{\circ} \mathrm{C}$ dan laju alir $5 \mathrm{ml} /$ menit mampu menghasikan nanokapsul ekstrak etanolik kulit melinjo merah dengan yield $31,98 \pm 0,11 \%$, efisiensi enkapsulasi $83,28 \pm 0,16 \%$ dan aktivitas antioksidan dengan penghambatan radikal
DPPH $\quad 69,94 \pm 0,07 \%$ dan reducing power 77,57 $\pm 0,43 \%$.

\section{DAFTAR PUSTAKA}

Ali, D,Y., 2013. Optimasi Nanoenkapsulasi Asap Cair Tempurung Kelapa dengan Response Surface Methodology. Tesis Magister. Universitas Gadjah Mada. Yogyakarta

Apriliyanti, M, -W., Ardiyansyah, -M., Handayani, A, -M., 2018. Antioxidant activity, total phenol, and sensory properties of melinjo peel tea with pretreatment. IOP Conference Series: Earth and Environmental Science. 207, 1-7. https://doi.org/10.1088/17551315/207/1/012044

Asprea, -M., Leto, -I., Bergonzi, M, -C., Bilia, A, -R., 2017. Thyme essential oil loaded in nanocochleates: Encapsulation efficiency, in vitro release study and antioxidant activity. LWT - Food Science and Technology. 77, 497-502. https://doi.org/10.1016/j.lwt.2016.12.00 6

Babu, T, -A., Kumar, -S., Smith, D, -D., Lakshmipathy, -R., 2019. The physicochemical properties of spraydried papaya leaf powders. International Journal of Current Microbiology and Applied Sciences. $\quad 8, \quad$ 139-146. https://doi.org/10.20546/ijcmas.2019.801.017

Bilgin, -M., Şahin, -S., 2013. Effects of geographical origin and extraction methods on total phenolic yield of olive tree (Olea europaea) leaves. Journal of the Taiwan Institute of Chemical Engineers. 44, 8-12. https://doi.org/10.1016/j.jtice.2012.08.008

Chowdary, K, P, -R., Srinivasan, -S., 2011. Effects of cyclodextrins, tween-80 and PVP on the solubility and dissolution rate of etoricoxib. Journal of Pharmaceutical Sciences and Research. 3(7), 1344-1348

Correâ-Filho, L, -C., Lourenço, M, -M., Moldaõ-Martins, -M., Alves, V, -D., 2019. Microencapsulation of $\beta$-Carotene by spray drying: Effect of wall material concentration and drying inlet temperature. International Journal of Food Science. 2019, 1-12. 
https://doi.org/10.1155/2019/8914852

Danaei, -M., Dehghankhold, -M., Ataei, -S., Davarani, -F, -H., Javanmard, -R., Dokhani, -A., Khorasani, -S., Mozafari, M. -R., 2018. Impact of particle size and polydispersity index on the clinical applications of lipidic nanocarrier systems. Pharmaceutics. 10, 1-17. https://doi.org/10.3390/pharmaceutics 10020057

Dehcheshmeh, M, -A., Fathi, -M., 2019. Production of core-shell nanofibers from zein and tragacanth for encapsulation of saffron extract. International Journal of Biological Macromolecules. 122, 272-279. https://doi.org/10.1016/j.ijbiomac.2018 .10 .176

Devina, N., 2011. Optimasi Proses Ekstraksi Kulit Melinjo Merah (Gnetum gnemon L.) dan Pengaruh $\mathrm{pH}$ dan Cahaya Terhadap Aktivitas Antioksidan. Skripsi Sarjana. Universitas Pelita Harapan. Karawaci

Dube, -A., Ng, -K., Nicolazzo, J, -A., Larson, -I., 2010. Effective use of reducing agents and nanoparticle encapsulation in stabilizing catechins in alkaline solution. Food Chemistry. 122, 662-667. https://doi.org/10.1016/j.foodchem.201 0.03.027

Falleh, -H., Ksouri, -R., Lucchessi, M, -E., Abdelly, -C., Magné, -C., 2012. Ultrasound-assisted extraction: Effect of extraction time and solvent power on the levels of polyphenols and antioxidant activity of Mesembryanthemum edule L. Aizoaceae shoots. Tropical Journal of Pharmaceutical Research. 11 , 243-249. https://doi.org/10.4314/tipr.v11i2.10

Fazaeli, -M., Emam-Djomeh, -Z., Ashtari, -A,K., Omid, -M., 2012. Effect of spray drying conditions and feed composition on the physical properties of black mulberry juice powder. Food and Bioproducts Processing. 90, 667-675. https://doi.org/10.1016/j.fbp.2012.04.006

Ho, L, -P., Pham, A, -H., Le, V, V, -M., 2015. Effects of core/wall ratio and inlet temperature on the retention of antioxidant compounds during the spray drying of sim (Rhodomyrtus tomentosa) juice. Journal of Food Processing and Preservation. 39, 2088-2095. https://doi.org/10.1111/jfpp.12452

Jafari, S, -M., Ghalenoei, -M, -G., Dehnad, -D.,
2017. Influence of spray drying on water solubility index, apparent density, and anthocyanin content of pomegranate juice powder. Powder Technology. 311, 59-65. https://doi.org/10.1016/j.powtec.2017.01.0 70

Kalogeropoulos, -N., Yannakopoulou, -K., Gioxari, -A., Chiou, -A., Makris, D, -P., 2010. Polyphenol characterization and encapsulation in $\beta$-cyclodextrin of a flavonoid-rich Hypericum perforatum (St John's wort) extract. LWT - Food Science and Technology. 43, 882-889. https://doi.org/10.1016/j.lwt.2010.01.016

Karaca, A, -C., Guzel, -O., Ak, M, -M., 2016. Effects of processing conditions and formulation on spray drying of sour cherry juice concentrate. Journal Of The Science of Food and Agriculture. 96, 449455. https://doi.org/10.1002/jsfa.7110

Krishnaiah, -D., Sarbatly, -R., Nithyanandam, -R., 2012. Microencapsulation of Morinda citrifolia L. extract by spray-drying. Chemical Engineering Research and Design. 90, 622-632. https://doi.org/10.1016/j.cherd.2011.09.003

Murugesan, -R., Orsat, -V., 2011. Spray drying of elderberry (Sambucus nigra L.) juice to maintain its phenolic content. Drying Technology. 29, 1729-1740. https://doi.org/10.1080/07373937.2011. 602485

Muzaffar, -K., Kumar, -P., 2015. Parameter optimization for spray drying of tamarind pulp using response surface methodology. Powder Technology. 279, 179-184. https://doi.org/10.1016/j.powtec.2015.04.010

Oroian, -M., Dranca, -F., Ursachi, -F., 2020. Comparative evaluation of maceration, microwave and ultrasonic-assisted extraction of phenolic compounds from propolis. Journal of Food Science and Technology. 57, 70-78. https://doi.org/10.1007/s13197-019-04031-x

Ozsoy, -N., Can, -A., Yanardag, -R., Akev, -N., 2008. Antioxidant activity of Smilax excelsa L. leaf extracts. Food Chemistry. 110, 571-583. https://doi.org/10.1016/jffoodchem.2008.02.037

Paini, -M., Aliakbarian, -B., Casazza, A,-A., Lagazzo, -A., Botter, -R., Perego, -P., 2015. Microencapsulation of phenolic compounds from olive pomace using spray drying: A study of operative parameters. LWT - Food Science and Technology. $\quad 62, \quad 177-186$. https://doi.org/10.1016/j.lwt.2015.01.022

Royshanpour, -S., Tavakoli, -J., Beigmohammadi, -F., 
Jurnal Teknologi Pertanian Vol. 22 No. 3 [Desember 2021] 211-220

Nanoenkapsulasi Ekstrak Kulit Melinjo Merah pada Berbagai Suhu Inlet dan Laju Air Spray Dryer

[Kunarto dkk]

Alaei, -S., 2021. Improving antioxidant effect of phenolic extract of Mentha piperita using nanoencapsulation process. Journal of Food Measurement and Characterization. 15, 23-32. https://doi.org/10.1007/s11694-020-00606-x

Salvia-Trujillo, -L., Rojas-Graü, M, -A., SolivaFortuny, -R., Martín-Belloso, -O., 2013. Effect of processing parameters on physicochemical characteristics of microfluidized lemongrass essential oilalginate nanoemulsions. Food Hydrocolloids. 30, 401-407. https://doi.org/10.1016/j.foodhyd.2012 .07 .004

Savić-Gajić, -I., Savić, I, -M., Nikolić, V, -D., Nikolić, L, -B., Popsavin, M, -M., Rakić, S, -J., 2017. The improvement of phtostability and antioxidant activity of trans-resveratrol by cyclodextrins. Advanced Technologies 6, 18-25. https://doi.org/10.5937/savteh1702018S

Shamaei, -S., Seiiedlou, S, -S., Aghbashlo, -M., Tsotsas, -E., Kharaghani, -A., 2017. Microencapsulation of walnut oil by spray drying: Effects of wall material and drying conditions on physicochemical properties of microcapsules. Innovative Food Science E Emerging Technologies. 39, 101-112. https://doi.org/10.1016/j.ifset.2016.11.011

Shrotriya, S, -N., Ranpise, N, -S., Vidhate, B, V., 2017. Skin targeting of resveratrol utilizing solid lipid nanoparticleengrossed gel for chemically induced irritant contact dermatitis. Drug Delivery and Translational Research. 7, 37-52. https://doi.org/10.1007/s13346-016-0350-7

Sugita, -P., Ambarsari, -L., Farichah, -F., 2013. Increasing amount and entrapment efficiency of chitosan-ketoprofen nanoparticle using utrasonication method with varied time and amplitude. IJRRAS. 14, 612-618.

Sukhbir, -S., Yashpal, -S., Sandeep, -A., 2016. Development and statistical optimization of nefopam hydrochloride loaded nanospheres for neuropathic pain using Box-Behnken design. Saudi Pharmaceutical Journal. 24, 588-599. https://doi.org/10.1016/j.jsps.2015.03.020

Surassmo, -S., Min, S, -G., Bejrapha, -P., Choi, M, -J., 2010. Effects of surfactants on the physical properties of capsicum oleoresin-loaded nanocapsules formulated through the emulsion- diffusion method. Food Research International. $\quad 43, \quad 8-17$. https://doi.org/10.1016/j.foodres.2009. 07.008

Talón, -E., Lampi, A, -M., Vargas, -M., Chiralt, -A., Jouppila, -K., González-Martínez, C., 2019. Encapsulation of eugenol by spray-drying using whey protein isolate or lecithin: Release kinetics, antioxidant and antimicrobial properties. Food Chemistry. 295, 588-598. https://doi.org/10.1016/j.foodchem.201 9.05.115

Tsai, C,-C., Chou, C,-H., Liu, Y,-C., Hsieh, C,W., 2014. Ultrasound-assisted extraction of phenolic compounds from Phyllanthus emblica L. and evaluation of antioxidant activities. International Journal of Cosmetic Science. $\quad 36, \quad 471-476$. https://doi.org/10.1111/ics.12143

Tupuna, D, -S., Paese, -K., Guterres, S, -S., Jablonski, -A., Flôres, S, -H., Rios, A, de O., 2018. Encapsulation efficiency and thermal stability of norbixin microencapsulated by spray-drying using different combinations of wall materials. Industrial Crops and Products. 111 , 846-855. https://doi.org/10.1016/j.indcrop.2017. 12.001

Yeni, G., 2015. Rekayasa Proses Nanoenkapsulasi Konsentrat Katekin dari Gambir (Uncaria gambir Roxb.) sebagai Antioksidan. Disertasi Doktor. IPB University. Bogor

Zhou, -C., Cheng, -X., Zhao, -Q., Yan, -Y., Wang, -J., Huang, -J., 2013. Selfassembly of nonionic surfactant tween $20 @ 2 \beta$-CD Inclusion complexes in dilute solution. Langmuir. 29, 13175-13182. https://doi.org/10.1021/la403257v

$Z u$, -Y., Wu, -W., Zhao, -X, Li, -Y., Wang, -W., Zhong, -C., Zhang, -Y., Zhao, -X, 2014. Enhancement of solubility, antioxidant ability and bioavailability of taxifolin nanoparticles by liquid antisolvent precipitation technique. International Journal of Pharmaceutics. 471, 366-376. https://doi.org/10.1016/j.ijpharm.2014. 05.049 